\title{
The cyclopropylcarbinyl route to $y$-silyl carbocations
}

\author{
Xavier Creary
}

Full Research Paper

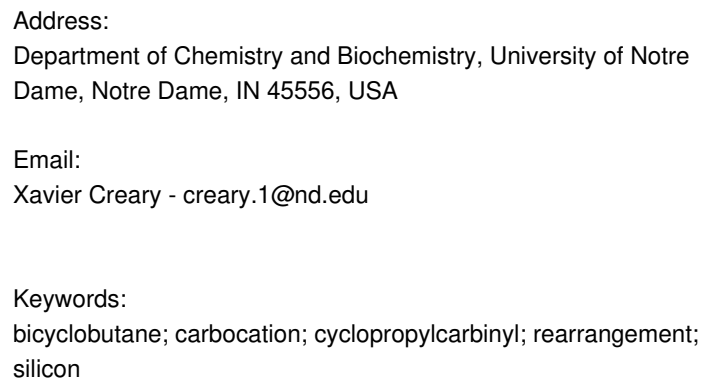

\author{
Beilstein J. Org. Chem. 2019, 15, 1769-1780. \\ doi:10.3762/bjoc. 15.170 \\ Received: 25 March 2019 \\ Accepted: 03 July 2019 \\ Published: 24 July 2019 \\ This article is part of the thematic issue "Reactive intermediates - \\ carbocations". \\ Guest Editor: S. R. Hare \\ (C) 2019 Creary; licensee Beilstein-Institut. \\ License and terms: see end of document.
}

\begin{abstract}
The mesylate derivative of cis-1-hydroxymethyl-2-trimethylsilylcyclopropane has been prepared, along with a number of related mesylates and triflates with substituents on the 1-position. These substrates all solvolyze in $\mathrm{CD}_{3} \mathrm{CO}_{2} \mathrm{D}$ to give products derived from cyclopropylcarbinyl cations that undergo further rearrangement to give 3-trimethylsilylcyclobutyl cations. These 3-trimethylsilylcyclobutyl cations are stabilized by a long-range rear lobe interaction with the $\gamma$-trimethylsilyl group. When the substituent is electron-withdrawing $\left(\mathrm{CF}_{3}, \mathrm{CN}\right.$, or $\left.\mathrm{CO}_{2} \mathrm{CH}_{3}\right)$, significant amounts of bicyclobutane products are formed. The bicyclobutanes are a result of $\gamma$-trimethylsilyl elimination from the cationic intermediate that has an unusually long calculated $\mathrm{Si}-\mathrm{C}$ bond. The solvolysis chemistry of mesylate and triflate derivatives of trans-1-hydroxymethyl-2-trimethylsilylcyclopropane and 1-substituted analogs can be quite different since these substrates do not generally lead to 3-trimethylsilylcyclobutyl cations.
\end{abstract}

\section{Introduction}

Carbocations, positively charged trivalent carbon compounds and reactive intermediates, have continued to fascinate chemists since the early discoveries of tropylium [1,2] and trityl [3-7] salts. Many of the giants of organic chemistry during the last century contributed heavily to the development of carbocation chemistry. This article will deal with three types of carbocations that have been of intense and fundamental interest over the years, i.e., cyclopropylcarbinyl cations, electron-deficient cations, and silyl substituted carbocations. A brief overview of these types of carbocations is warranted.
Cyclopropylcarbinyl cations are an extensively studied system $[8,9]$. Initial interest was derived from the fact that both cyclopropylcarbinyl and cyclobutyl substrates $\mathbf{1}$ and $\mathbf{2}$, where $\mathrm{X}$ represents diazonium ion $[10,11]$, chloride [10], or naphthalenesulfonate [12] leaving groups, reacted in aqueous solvents to give an identical mixture of products $\mathbf{3}, \mathbf{4}$, and $\mathbf{5}$ (Scheme 1). Additionally, solvolysis rates were far greater than expected for primary and strained secondary systems. To account for these facts, it has been suggested that there are common cationic intermediates in these solvolysis reactions of $\mathbf{1}$ and $\mathbf{2}$. Labelling 
[13-15], stable ion [16-19], and computational studies [19] implicate the involvement of three degenerate cyclopropylcarbinyl cations, $\mathbf{6 a}, \mathbf{6 b}$, and $\mathbf{6 c}$, in equilibrium with cyclobutyl cation $\mathbf{7}$, as well as the homoallylic cation $\mathbf{8}$ (Scheme 2). Cations $\mathbf{6}$ are stabilized by the cyclopropyl ring and are therefore much more stable than simple primary carbocations. The cyclobutyl cation $\mathbf{7}$ is also quite stabilized relative to simple secondary carbocations. This cation has been called a "bicyclobutonium" cation, 7a, which is a nonclassical cation (a cation containing hypercoordinated carbon) that could be derived from protonation of bicyclobutane [20]. Another potential mode of stabilization is by an interaction of the cationic center with the adjacent strained cyclobutyl bonds as in $\mathbf{7 b}$.

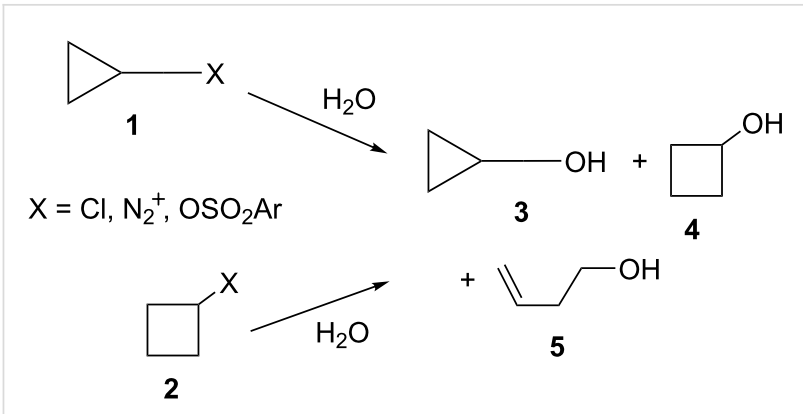

Scheme 1: Solvolyses of cyclopropylcarbinyl and cyclobutyl substrates.

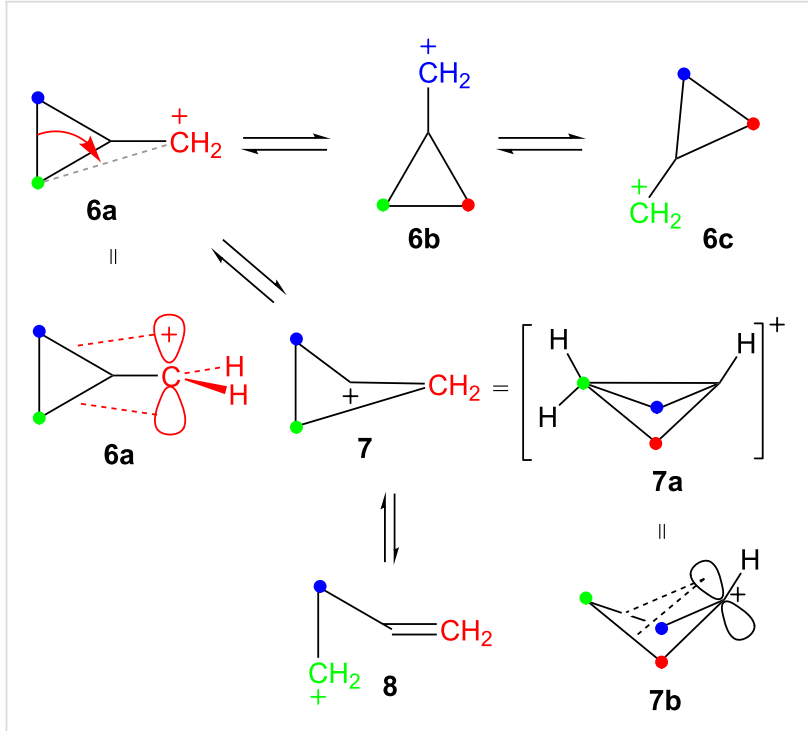

Scheme 2: The cyclopropylcarbinyl-cyclobutyl-homoallyl cation manifold.

A second class of carbocations that this article will deal with is the so-called "electron-deficient" carbocation, i.e., carbocations 9 (Figure 1) substituted with electron-withdrawing groups E [21]. Many studies have shown that such cations can indeed be generated and that they can derive stabilization by a variety of mechanisms. Chief among these cations are the $\alpha$-trifluoromethyl [22-24], $\alpha$-cyano [22,25-29], $\alpha$-carbonyl [30-33], and $\alpha$-phosphoryl [34,35] analogs of 9 . Carbocations of type 9 will be examined in conjunction with the cyclopropylcarbinyl-cyclobutyl manifold.

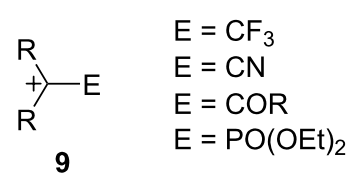

Figure 1: Electron-deficient carbocations.

The third type of carbocation that will be incorporated into this paper is the trimethylsilyl-substituted carbocation [36-44]. We have been interested in long-range interactions of silicon with both carbene [45-48] and carbocation centers [49,50]. Along these lines, $\gamma$-trimethylsilyl cations of general type $\mathbf{1 1}$ have been generated under stable-ion [51] as well as solvolytic conditions [52-54]. They are greatly stabilized by the "rear lobe" type of interaction shown involving the $\gamma$-trimethylsilyl group. A number of related cations are also stabilized by analogous $\gamma$-silyl interactions [55-59], which have also been termed "percaudal" interactions [56]. Certain carbenes can also be stabilized in a similar fashion [60,61]. Thus substrates of type $\mathbf{1 0}$ solvolyze in protic solvents with large rate enhancements (anchimeric assistance) to generate carbocations $\mathbf{1 1}$ as reactive intermediates (Scheme 3). These cations $\mathbf{1 1}$ capture solvent molecules to give exclusively products $\mathbf{1 2}$ with net retention of configuration, a characteristic of carbocations that are stabilized by this type of rear lobe interaction.

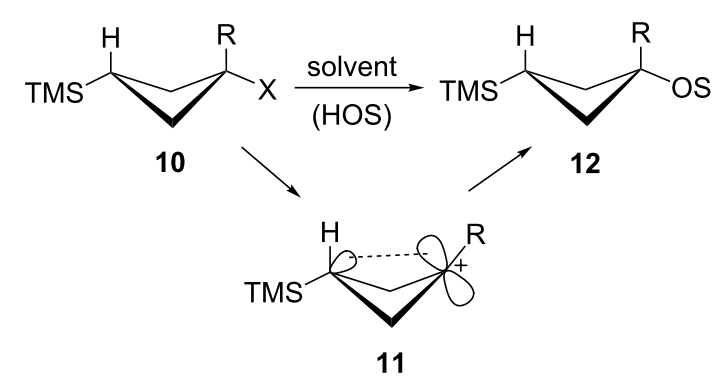

Scheme 3: Solvolyses of $\gamma$-trimethylsilylcyclobutyl substrates.

A series of cyclopropylcarbinyl substrates 13 and 14 (Figure 2), where $\mathrm{X}$ is a leaving group and $\mathrm{R}$ is an electron-donating group and $\mathrm{E}$ is an electron-withdrawing group, have now been examined. The goal was to evaluate the cyclopropylcarbinyl to cyclobutyl cation rearrangement. Can these substrates lead to 
$\gamma$-trimethylsilyl-substituted cyclobutyl cations $\mathbf{1 1}$ and what are the fates of such carbocations? Answers to these questions were sought.
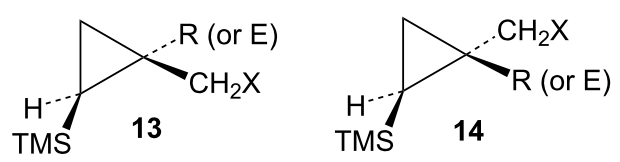

Figure 2: Substrates of interest.

\section{Results and Discussion Phenyl-substituted systems}

The first compounds to be examined were the mesylates 19 and 20. These substrates were prepared as shown in Scheme 4. Irradiation of ethyl 2-diazo-2-phenylacetate (15) in vinyltrimethylsilane as solvent gave an isomeric mixture of esters 16. Subsequent reduction with lithium aluminum hydride gave a mixture of alcohols $\mathbf{1 7}$ and $\mathbf{1 8}$, which could be readily separated by silica gel chromatography. The assignment of stereochemistry of these isomers was based on shielding effects in both ${ }^{1} \mathrm{H}$ and ${ }^{13} \mathrm{C}$ NMR spectra. For example, the trimethylsilyl singlet in $\mathbf{1 8}$ appears at $\delta-0.30$ (shielded by the cis-phenyl group), while the trimethylsilyl singlet in $\mathbf{1 7}$ appears at $\delta 0.14$ (deshielded by the trans-phenyl group). Such effects are in complete agreement with calculated shifts based on B3LYP/6-31G* calculated structures of $\mathbf{1 7}$ and 18. Additionally, nOe studies on $\mathbf{1 7}$ confirm the stereochemical assignment. Conversion to mesylates $\mathbf{1 9}$ and $\mathbf{2 0}$ using mesyl chloride and triethylamine was straightforward.

Mesylate 19 reacts readily in $\mathrm{CD}_{3} \mathrm{CO}_{2} \mathrm{D}$ at $20{ }^{\circ} \mathrm{C}$ (Table 1) to give the substituted cyclobutyl acetate $\mathbf{2 1}(92 \%)$ as the major

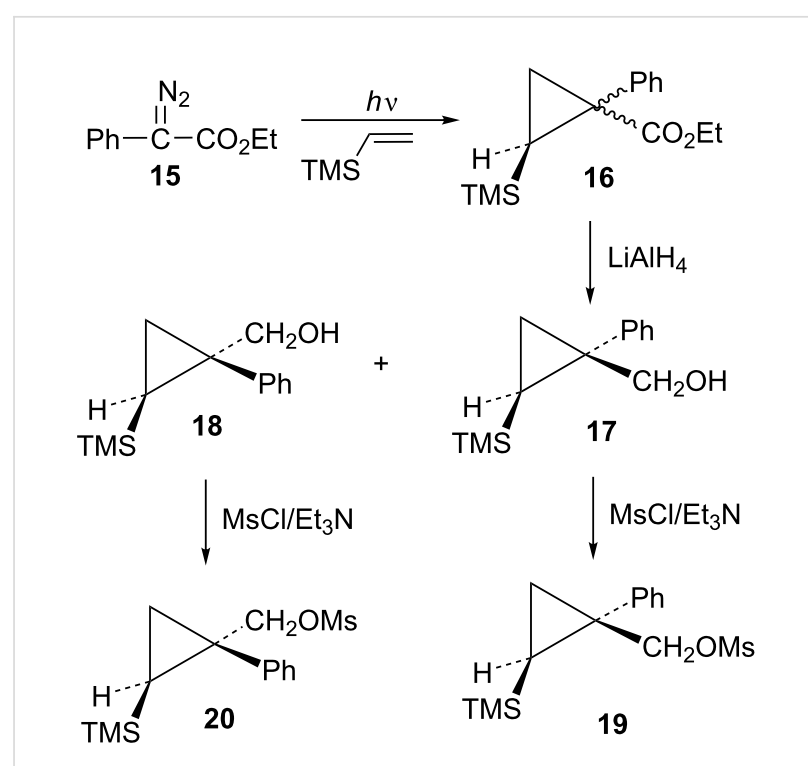

Scheme 4: Synthesis of mesylates 19 and 20.

product along with $8 \%$ of the alkene 22 . It is proposed (Scheme 5) that these products arise from stepwise formation of the cyclopropylcarbinyl cation $\mathbf{2 3}$. This cation can rearrange via migration of bond $a$ to give the cyclobutyl cation $\mathbf{2 4}$. The cisnature of the phenyl group and the hydrogen in cation $\mathbf{2 3}$ necessarily results in the formation of the $\gamma$-silyl-stabilized cation $\mathbf{2 4}$. This cation is the source of the acetate 21. Alternatively, cation 23 can rearrange by migration of the $b$ bond of the cyclopropane. This leads to the $\beta$-silylcyclobutyl cation $\mathbf{2 5}$, which can subsequently desilylate to give the minor product, the alkene 22. Interestingly, formation of the $\gamma$-silyl cation $\mathbf{2 4}$ is preferred over the $\beta$-silyl cation $\mathbf{2 5}$.

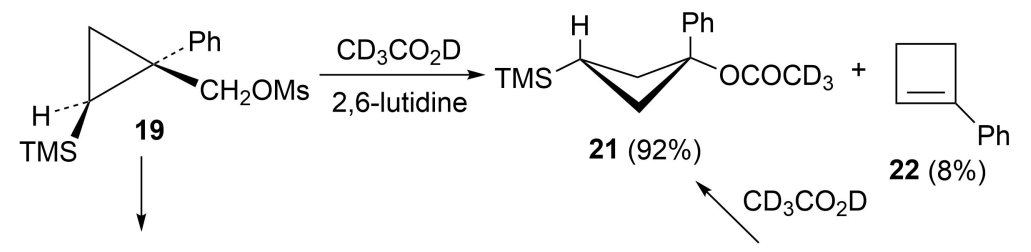

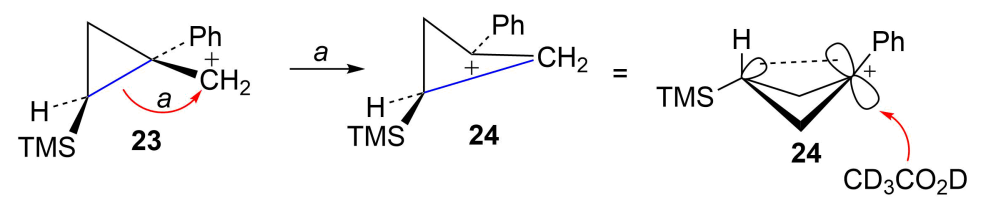

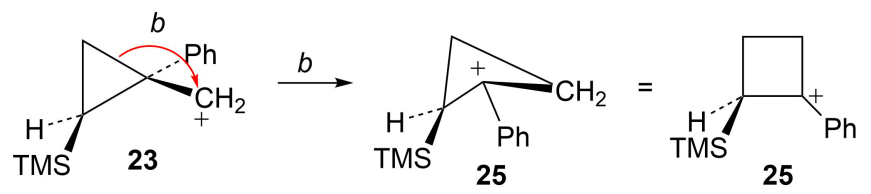


Reaction of the isomeric mesylate 20 in $\mathrm{CD}_{3} \mathrm{CO}_{2} \mathrm{D}$ gives the same rearranged products $\mathbf{2 1}$ and $\mathbf{2 2}$. These products are accounted for mechanistically in Scheme 6. The initially formed cyclopropylcarbinyl cation $\mathbf{2 6}$ rearranges by migration of the $a$ bond of the cyclopropane to give the cyclobutyl cation 27 . This cation $\mathbf{2 7}$ is different from the $\gamma$-silyl-stabilized cation $\mathbf{2 4}$ in that the cis-nature of the phenyl and TMS groups in $\mathbf{2 6}$ requires that these groups are closer to each other in 27. Shown in Figure 3 are M062X/6-311+G** calculated structures and energies of cations $\mathbf{2 7}$ and $\mathbf{2 4}$, which are distinct energy minima, along with the transition state $\mathbf{2 8}$ which connects these two cations. Cation $\mathbf{2 7}$ derives most of its stabilization from the phenyl group, while

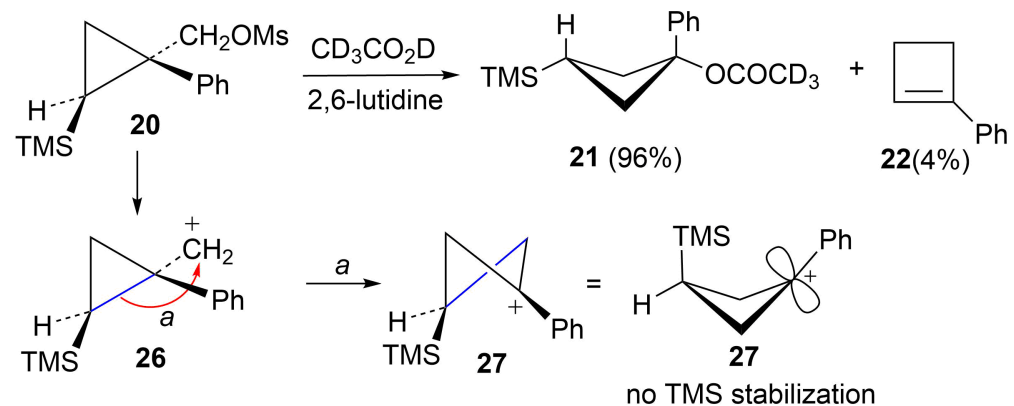

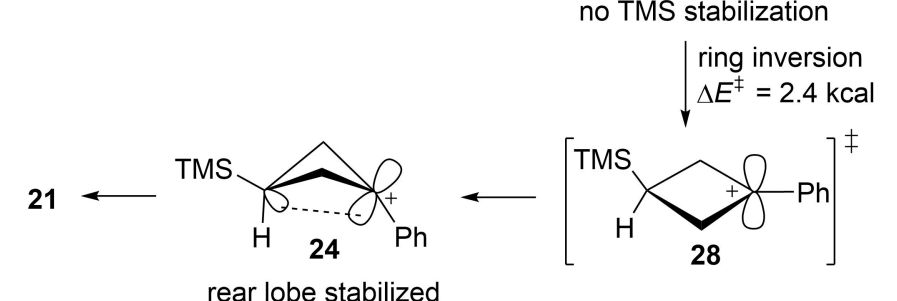

rear lobe stabilized

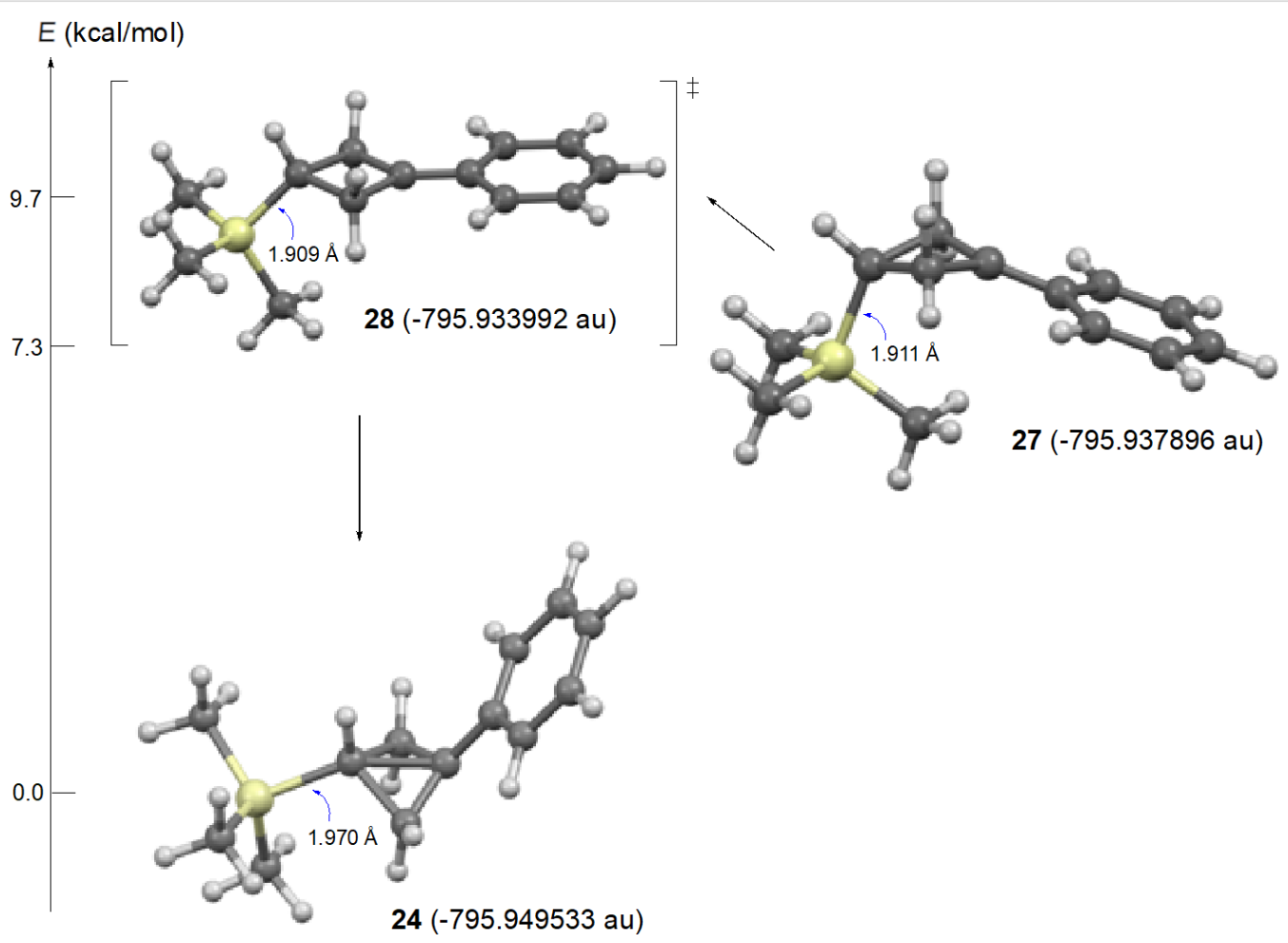

Figure 3: M062X/6-311+G** calculated structures and relative energies of cations 24, 27, and transition state 28. 
the TMS group in the 3-position provides no cross-ring stabilization. The calculated barrier for ring inversion of $\mathbf{2 7}$ to give the lower energy rear lobe stabilized $\gamma$-trimethylsilyl cation $\mathbf{2 4}$ is only $2.4 \mathrm{kcal} / \mathrm{mol}$. Calculations at the $\mathrm{B} 3 \mathrm{LYP} / 6-31 \mathrm{G}^{*}$, B3LYP/6-311+G**, MP2/6-31G*, and the MP2/6-311+G** levels lead to the same conclusions, i.e., cations $\mathbf{2 4}$ and $\mathbf{2 7}$ are distinct energy minima with a very low barrier for conversion of $\mathbf{2 7}$ to $\mathbf{2 4}$. Therefore, formation of $\mathbf{2 7}$ under solvolytic conditions should readily yield $\mathbf{2 4}$, and subsequently the substitution product 21 . The small amount (4\%) of elimination product $\mathbf{2 2}$ is a result of rearrangement of $\mathbf{2 6}$ to the $\beta$-trimethylsilyl cation $\mathbf{2 5}$ as described in Scheme 5.

\section{Unsubstituted and methyl-substituted systems}

Attention was next turned to potential $\gamma$-trimethylsilylcyclobutyl cation systems lacking phenyl stabilization. Thus pure $Z$ - and $E$-alcohols $\mathbf{2 9}$ and $\mathbf{3 0}$ were each cyclopropanated under Simmons-Smith conditions, and the resultant stereochemically pure alcohols were converted to mesylates $\mathbf{3 1}$ and $\mathbf{3 2}$, respectively (Scheme 7). For rate comparisons, cyclopropylcarbinyl mesylate 33 [62,63] was also prepared.<smiles>CS(=O)(=O)/C=C\CO</smiles>

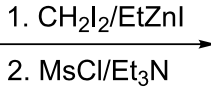<smiles>CS(=O)(=O)/C=C\CO</smiles>
$\underset{\text { 1. } \mathrm{CH}_{2} \mathrm{I}_{2} / \mathrm{EtZnl}}{\text { 2. } \mathrm{MsCl} / \mathrm{Et}_{3} \mathrm{~N}}$<smiles>COCC1CC1</smiles>
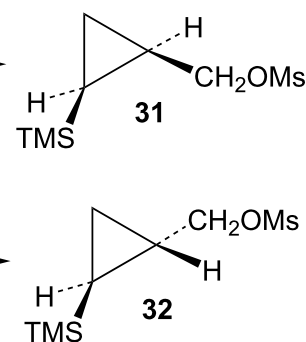
33

Scheme 7: Synthesis of mesylates $\mathbf{3 1}$ and $\mathbf{3 2}$.
Mesylate 31 reacted readily in $\mathrm{CD}_{3} \mathrm{CO}_{2} \mathrm{D}$ to give the ciscyclobutyl acetate $\mathbf{3 4}$ as the major product (Scheme 8), along with a small amount of cyclobutene (35). The rate of $\mathbf{3 1}$ (Table 1) is not substantially enhanced relative to the unsubstituted cyclopropylcarbinyl mesylate (33). The small rate enhancement factor of 3.56 is consistent with a small inductive stabilization of the initially formed cationic intermediate. This behavior is completely analogous to that of the phenyl analog 19 and a similar mechanistic pathway is proposed. The initially formed cyclopropylcarbinyl cation 36 rearranges to the $\gamma$-silylcyclobutyl cation $\mathbf{3 7}$, the source of the major product $\mathbf{3 4}$. The desilylated product $\mathbf{3 5}$ arises from the alternative $\beta$-trimethylsilylcyclobutyl cation.

The behavior of mesylate $\mathbf{3 2}$ is in contrast to that of $\mathbf{3 1}$ and the phenyl analog 20. Five products, 35, 38, 39, 40, and 41, are obtained and these products are formed in essentially the identical ratio as seen in our previous study of the trans-mesylate $\mathbf{4 2}$ [52]. The similarity of products formed from acetolysis of $\mathbf{3 2}$ and $\mathbf{4 2}$ implies that the same cation rearrangement manifold is involved. Scheme 9 gives a mechanistic rationale for these products. Capture of an unrearranged discrete cyclopropylcarbinyl cation $\mathbf{4 3}$ gives the major product $\mathbf{3 8}$, while migration of bond $c$ to the cationic center gives rearranged cation $\mathbf{4 4}$, the source of the rearranged acetate 39. Ring expansion via migration of bond $b$ in $\mathbf{4 3}$ gives the $\beta$-trimethylsilyl-stabilized cyclobutyl cation $\mathbf{4 5}$, and subsequent desilylation provides cyclobutene (35). Alternatively, cyclobutyl to homoallylic cation rearrangement leads to the homoallylic products $\mathbf{4 0}$ and 41 via internal mesylate return or solvent capture. Of interest is the fact that no product $\mathbf{3 4}$ (derived from $\gamma$-trimethylsilyl-stabilized cation 37) is formed. Our previous computational study [52] provided insight into the lack of involvement of cation $\mathbf{3 7}$. This study at the B3LYP/6-31G* level suggested that migration of bond $a$ in $\mathbf{4 3}$ is not viable since the resultant cation $\mathbf{4 7}$ is not an energy minimum at this level, but a transition state. However, a current study at the M062X/6-311+G** level finds

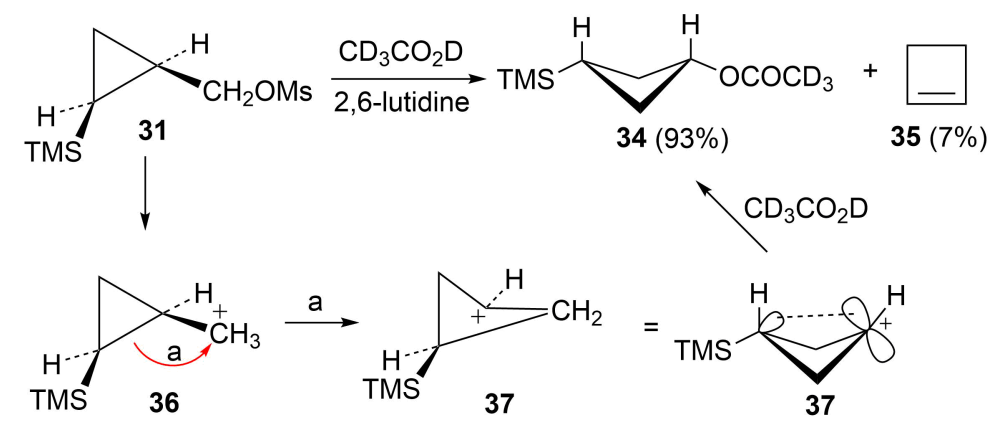

Scheme 8: Reaction of mesylate 31 in $\mathrm{CD}_{3} \mathrm{CO}_{2} \mathrm{D}$. 


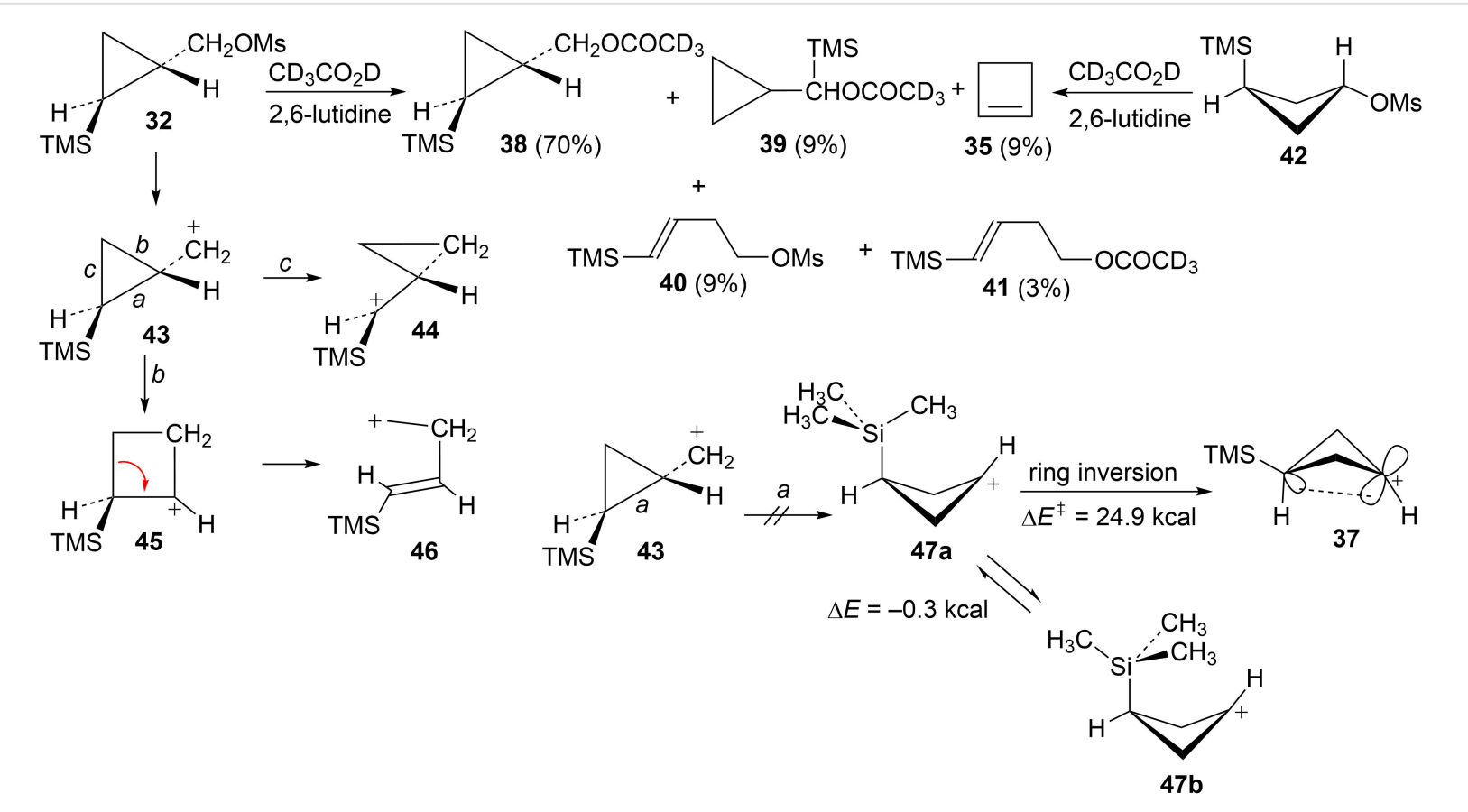

Scheme 9: Reaction of mesylate 32 in $\mathrm{CD}_{3} \mathrm{CO}_{2} \mathrm{D}$.

that both conformations $\mathbf{4 7 a}$ and $\mathbf{4 7} \mathbf{b}$ are energy minima. While 47a lies $10.8 \mathrm{kcal} / \mathrm{mol}$ above 37 , the barrier for inversion of $\mathbf{4 7 a}$ to $\mathbf{3 7}$ is quite large $(24.9 \mathrm{kcal} / \mathrm{mol})$. Hence there is no viable route to 37 .

In order to complete the study of substrates $\mathbf{1 3}$ with electron-donating groups, the methyl analog $\mathbf{4 8}$ was prepared from the corresponding cyclopropylcarbinyl alcohol, which was available from methyl 2-diazopropanoate by a process completely analogous to the synthesis of the phenyl analog $\mathbf{1 7}$. The mesylate derivative was too reactive for rates to be measured and hence the trifluoroacetate derivative $\mathbf{4 8}$ was studied. Acetolysis gave the acetate $\mathbf{5 0}$ along with a smaller amount of methylcyclobutene (51, Scheme 10). This reactivity is completely analogous to that seen in the phenyl and hydrogen analogs 19 and 31, i.e., a mechanistic scheme involving the $\gamma$-trimethylsilyl-stabilized cation $\mathbf{5 2}$ is likely.

The isomeric trifluoroacetate 49 (shown in Table 1) gives methylcyclobutene (51) (68\%) as the major acetolysis product, along with minor products that are identical to those previously reported [52] in solvolysis of the trifluoroacetate derivative of $(1 r, 3 r)$-1-methyl-3-(trimethylsilyl)cyclobutanol. As in the case of mesylate 32, the $\gamma$-trimethylsilyl-stabilized cation $\mathbf{5 2}$ is apparently not formed from trifluoroacetate $\mathbf{4 9}$ due to stereochemical constraints.

\section{Systems with electron-withdrawing groups}

Attention was next turned to cyclopropylcarbinyl systems substituted with electron-withdrawing groups. Previously Tilley
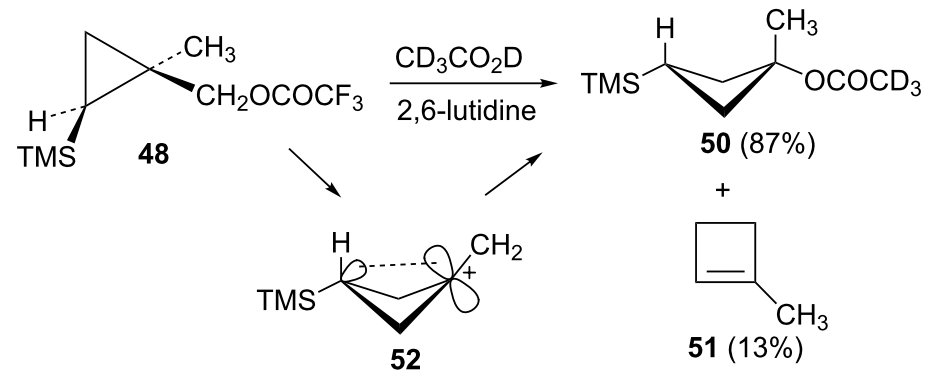
Table 1: Solvolysis rates for substrates in $\mathrm{CD}_{3} \mathrm{CO}_{2} \mathrm{D}$ at $20.0^{\circ} \mathrm{C}$.

\begin{tabular}{lll} 
& $k\left(\mathrm{~s}^{-1}\right)$ & $\begin{array}{l}k_{\text {rel }} \\
\text { (for } \mathrm{ROMs} \text { ) }\end{array}$ \\
\hline & & \\
\hline
\end{tabular}

aExtrapolated from data at higher temperatures. $k$ for 48 at $60.0{ }^{\circ} \mathrm{C}=$ $2.58 \times 10^{-5} \mathrm{~s}^{-1} ; k$ for 48 at $80.0^{\circ} \mathrm{C}=2.33 \times 10^{-4} \mathrm{~s}^{-1} ; k$ for 49 at $60.0{ }^{\circ} \mathrm{C}=1.62 \times 10^{-5} \mathrm{~s}^{-1} ; \mathrm{k}$ for 49 at $80.0^{\circ} \mathrm{C}=1.42 \times 10^{-4} \mathrm{~s}^{-1}$. ${ }^{\mathrm{b}}$ Mesylate is too reactive for rate to be measured. ${ }^{\mathrm{C}}$ Assuming mesylate reacts $10^{5}$ faster than trifluoroacetate.

and co-workers [55] have examined the triflate $\mathbf{5 3}$ and found that this system solvolyzes with rear lobe TMS participation (Scheme 11). The unusual feature in solvolysis of $\mathbf{5 3}$ is the formation of the highly strained bicyclobutane $\mathbf{5 5}$ as the sole product. It was therefore of interest to see if the cyclopropylcarbinyl to cyclobutyl rearrangement could be used to access the carbocation 54, and subsequently, bicyclobutane 55. It was also of interest to see if other bicyclobutanes could be formed if the $\mathrm{CF}_{3}$ group were replaced by other electron-withdrawing groups that we have previously examined in carbocation forming reactions.

The requisite trifluoromethyl-substituted cyclopropylcarbinyl systems were prepared by addition of the carbene derived from the diazoester $\mathbf{5 6}$ to vinyltrimethylsilane as shown in

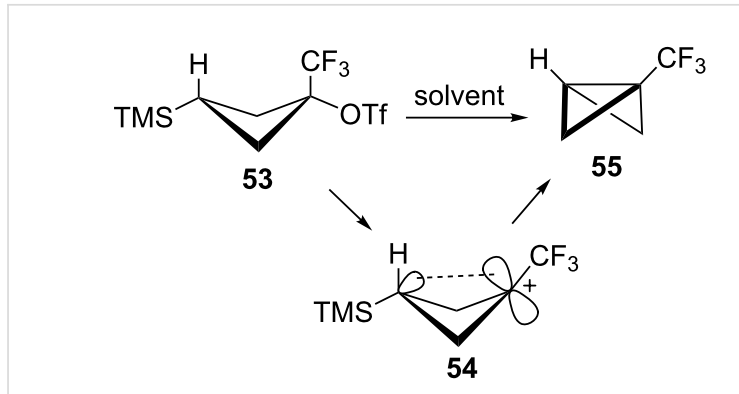

Scheme 11: Bicyclobutane formation from a $y$-trimethylsilyl cation.

Scheme 12. Reduction of the ester mixture 57 with lithium aluminum hydride gave a chromatographically separable mixture of alcohols $\mathbf{5 8}$ and 59. Stereochemistry of the alcohol $\mathbf{5 8}$ was established by long-range ${ }^{19} \mathrm{~F}$ coupling to the cis-trimethylsilyl group hydrogens $\left(J_{\mathrm{H}-\mathrm{F}}=0.9 \mathrm{~Hz}\right)$. Long-range ${ }^{19} \mathrm{~F}$ coupling to the TMS methyl groups of $\mathbf{5 8}$ was also observed in the ${ }^{13} \mathrm{C}$ NMR spectrum $\left(J_{\mathrm{C}-\mathrm{F}}=2.1 \mathrm{~Hz}\right)[64,65]$. This long-range ${ }^{19} \mathrm{~F}$ coupling is not observed when the $\mathrm{CF}_{3}$ group is trans to the TMS group in the isomer $\mathbf{5 9}$.

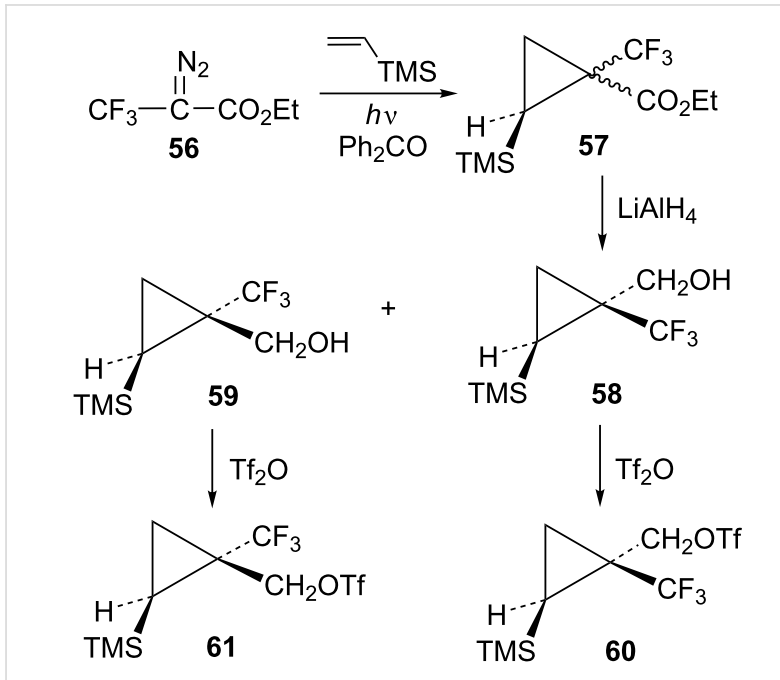

Scheme 12: Formation of triflates 60 and 61.

Additional cyclopropylcarbinyl systems containing the electronwithdrawing cyano and carbomethoxy groups were prepared in an analogous fashion as shown in Scheme 13. Carbomethoxycyano carbene addition to vinyltrimethylsilane followed by lithium borohydride reduction of the ester functionality of $\mathbf{6 3}$ gave a separable mixture of alcohols 64 and 65 . The stereochemistry of the product $\mathbf{6 5}$ was established using nOe studies. Cyano to carbomethoxy conversion in $\mathbf{6 5}$ to give alcohol $\mathbf{6 6}$ was straightforward. Triflate derivatives $\mathbf{6 7}$ and $\mathbf{6 8}$ were prepared since analogous mesylate derivatives were relatively unreactive. Triflate 69 was a highly reactive substrate that could only be 
<smiles>COC(=O)C([O-])([18O])C#N</smiles><smiles>COC(=O)[C@]1(C#N)C[C@H]1[AsH3]</smiles>

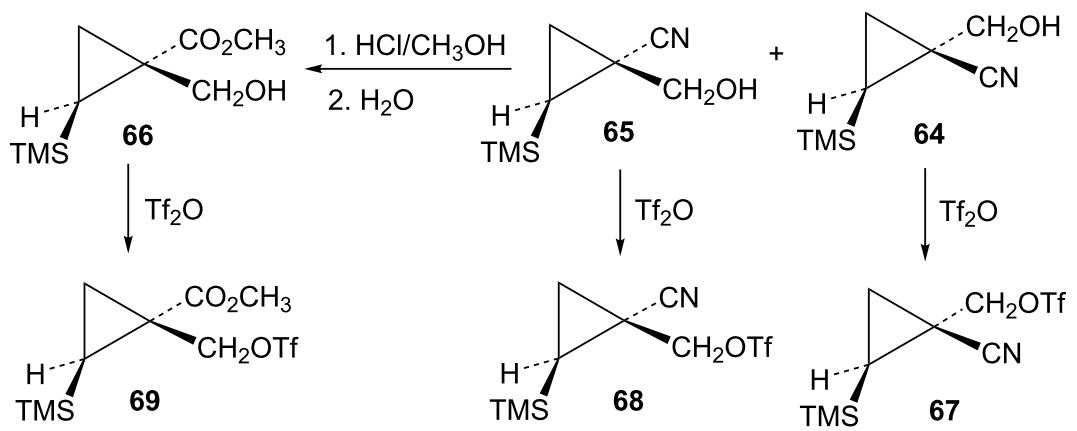

Scheme 13: Formation of triflates 67,68 , and 69.

prepared in about $80 \%$ purity. The less reactive mesylate derivative $\mathbf{7 5}$ was therefore prepared and used for kinetic studies.

The triflates 61, 68, and 69 (with electron-withdrawing groups trans to trimethylsilyl) were all solvolyzed in $\mathrm{CD}_{3} \mathrm{CO}_{2} \mathrm{D}$ and results are shown in Scheme 14. Since the triflate 69 was highly reactive and could not be isolated in pure form, the mesylate derivative 75 was used in kinetic studies that were carried out in the $40-60{ }^{\circ} \mathrm{C}$ range. Rates of reaction of mesylate derivatives (Table 2) were all substantially slower than the parent mesylate 33 or the phenyl, methyl, or $\mathrm{H}$ analogs. This is attributed to a significant inductive destabilizing $\beta$-effect of the group $\mathrm{E}$ on the initially formed cation $\mathbf{7 3}$. The triflates all produced significant amounts of bicyclobutane products $\mathbf{5 5}$ and $\mathbf{7 2}$ along with some unrearranged substitution products $\mathbf{7 0}$. In the cases of $\mathbf{6 8}$ and 69, some rearranged substitution products 71 were also formed. The mesylate $\mathbf{7 5}$ gave the same initial products as the triflate 69. However, the bicyclobutane $\mathbf{7 2 c}$ formed from mesylate $\mathbf{7 5}$ was not completely stable at $40-60^{\circ} \mathrm{C}$, but degraded slowly to a mixture of other products. The bicyclobutanes $\mathbf{5 5}, \mathbf{7 2 b}$, and $\mathbf{7 2 c}$ were quite stable in $\mathrm{CD}_{3} \mathrm{CO}_{2} \mathrm{D}$ at $20^{\circ} \mathrm{C}$, where triflate studies were carried out.

The bicyclobutane products $\mathbf{5 5}$ and $\mathbf{7 2}$ are a result of desilylation of the $\gamma$-silyl cations $\mathbf{5 4}$ and 74. Why are bicylobutanes formed from cations $\mathbf{5 4}$ and $\mathbf{7 4}$ and not from cations 24, 37, and 52, which do not have electron-withdrawing groups? Previous studies have shown that "electron-deficient" cations $\mathbf{9}$, where

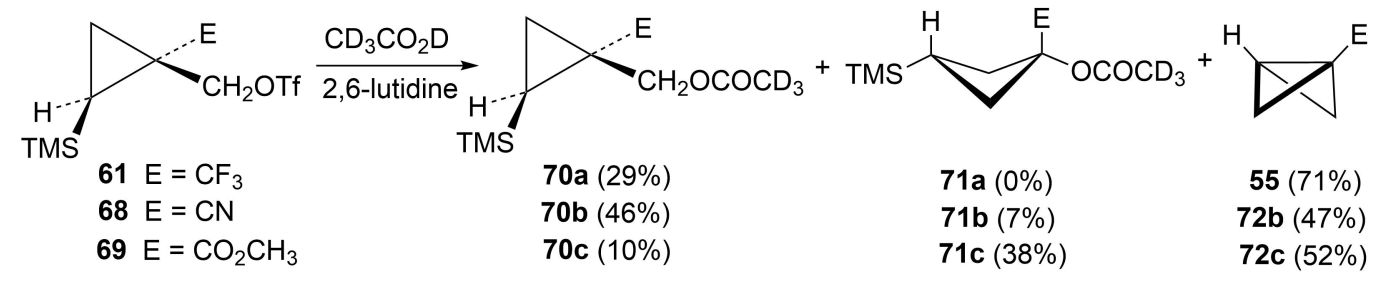


Table 2: Solvolysis rates for substrates in $\mathrm{CD}_{3} \mathrm{CO}_{2} \mathrm{D}$ at $20.0^{\circ} \mathrm{C}$

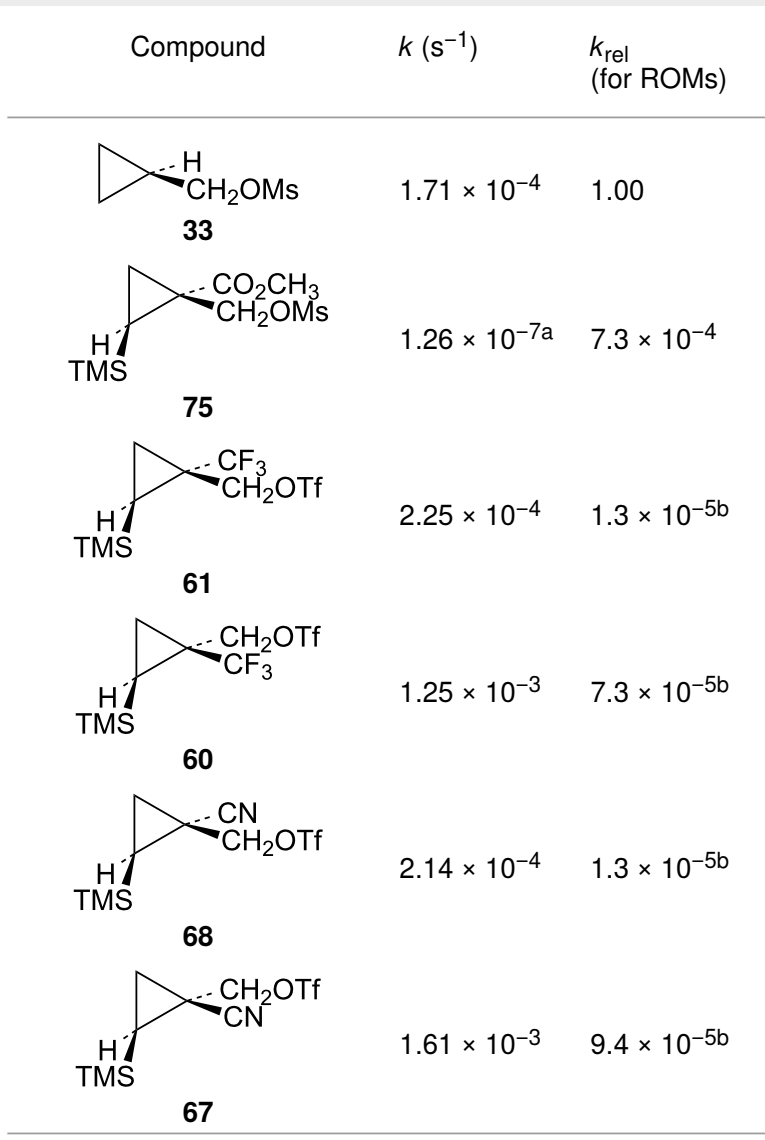

aExtrapolated from data at higher temperatures. $k$ at $40.0^{\circ} \mathrm{C}=$ $2.24 \times 10^{-6} \mathrm{~s}^{-1} ; \mathrm{k}$ at $50.0^{\circ} \mathrm{C}=8.40 \times 10^{-6} \mathrm{~s}^{-1} ; \mathrm{k}$ at $60.0^{\circ} \mathrm{C}=$ $2.85 \times 10^{-5} \mathrm{~s}^{-1}$. ${ }^{\mathrm{b}}$ Assuming triflate reacts $10^{5}$ faster than mesylate.
$\mathrm{E}=\mathrm{COR}$ [66], $\mathrm{CN}$ [25], $\mathrm{CF}_{3}$ [67], and $\mathrm{PO}(\mathrm{OEt})_{2}$ [34], readily eliminate $\beta$-hydrogens to form alkenes as major products. They do not readily capture solvent at the cationic center. It is therefore expected that nucleophilic attack at the cationic centers of 54 and 74 will be slowed. Table 3 shows results of calculations on the $\gamma$-trimethylsilylcyclobutyl cations shown in Figure 4 at different levels of theory. The presence of the electron-withdrawing group results in an increase in the $\mathrm{Si}-\mathrm{C} 3$ bond length relative to the cations 24 and $\mathbf{5 2}$. Also, the cross-ring C1-C3 distance is decreased. In the language of resonance theory, these features are in line with increased contributions of form 74a to the overall structure of the cation. These features suggest more facile nucleophilic attack should occur at silicon, favoring bicyclobutane formation. Also included in Table 3 are calculated bond lengths in the phosphoryl-substituted cation 74d, which also shows a very long Si-C bond. Preferred trimethylsilyl elimination from this intermediate is in line with the behavior of mesylate 76, which gives exclusively the bicyclobutane 77 on solvolysis in $\mathrm{CH}_{3} \mathrm{CO}_{2} \mathrm{H}$ (Scheme 15).

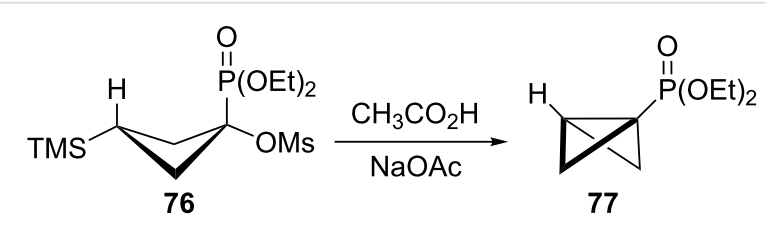

Scheme 15: Bicyclobutane formation from mesylate 76 in $\mathrm{CH}_{3} \mathrm{CO}_{2} \mathrm{H}$.

The final item to be addressed is the behavior of triflates $\mathbf{6 0}$ and 67 with electron-withdrawing $\mathrm{CF}_{3}$ and $\mathrm{CN}$ groups cis to the tri-<smiles>[Z4]C1CCCCC1c1ccccc1</smiles>

24<smiles></smiles>

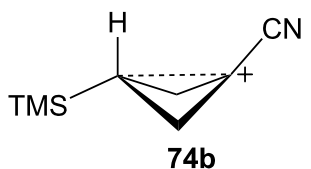

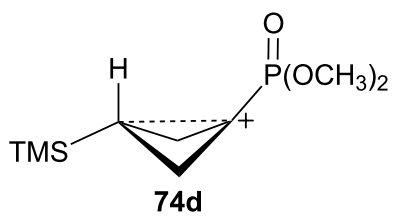<smiles>C[C@H]1CC[C@@H](C)C1</smiles>

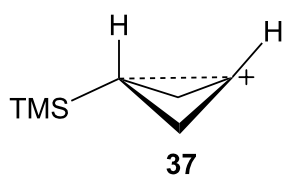

37<smiles>CS(=O)(=O)CCC(C(F)(F)F)C(F)(F)F</smiles>
$\mathrm{TMS}^{+}$<smiles>[Z10]C1CC1(F)C1CC1</smiles> 


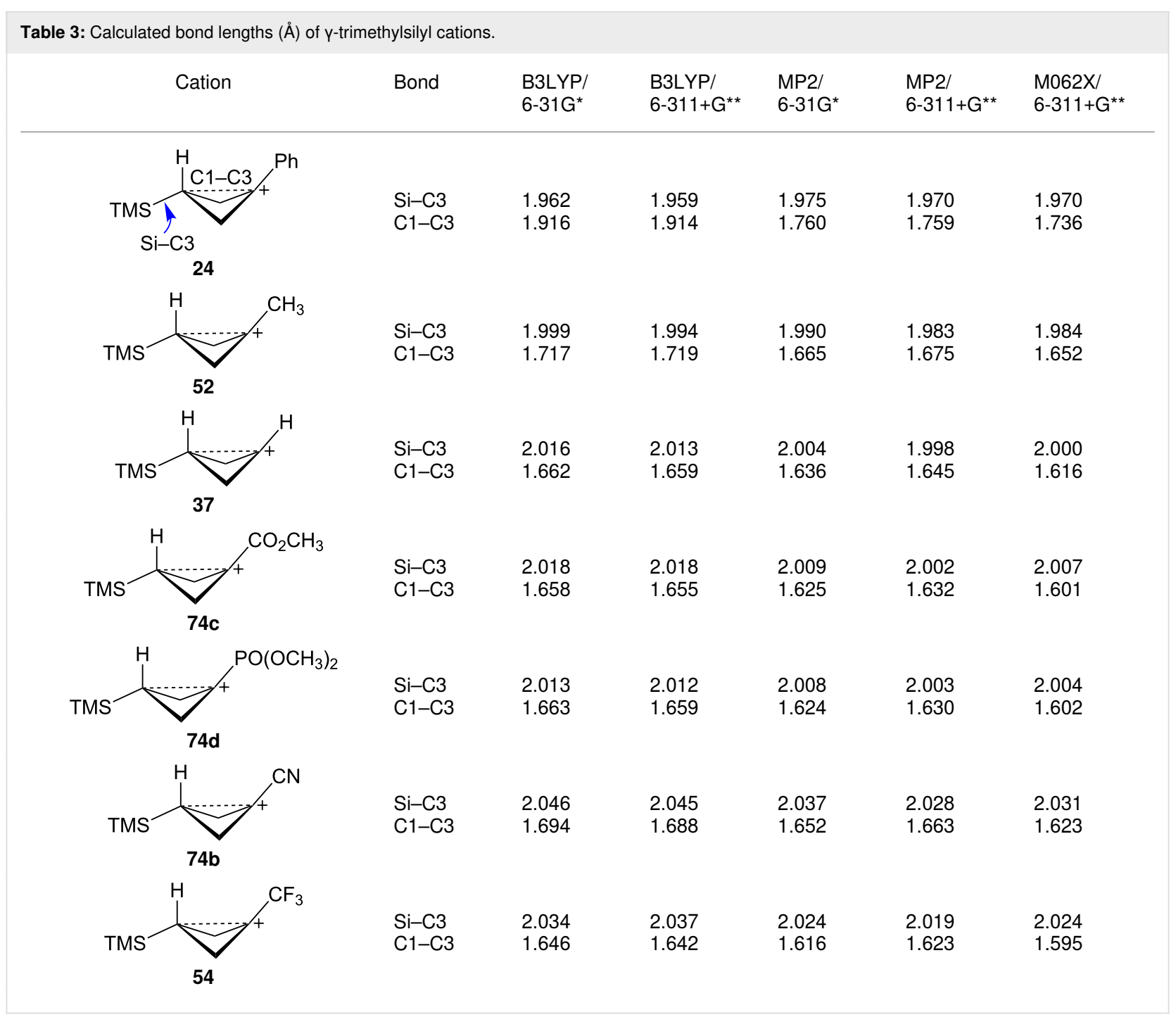

methylsilyl group. These substrates gave exclusively unrearranged substitution products $\mathbf{7 8}$ and $\mathbf{7 9}$ when reacted in $\mathrm{CD}_{3} \mathrm{CO}_{2} \mathrm{D}$ (Scheme 16). The lack of rearrangement products suggests that these potent electron-withdrawing groups make

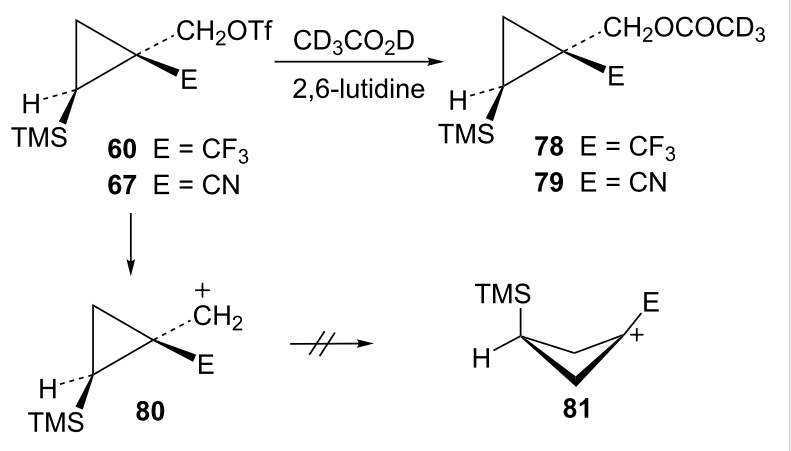

Scheme 16: Reactions of triflates 60 and 67 in $\mathrm{CD}_{3} \mathrm{CO}_{2} \mathrm{D}$. further rearrangement of cations $\mathbf{8 0}$ untenable. Indeed, M062X/ $6-311+\mathrm{G}^{* *}$ calculations show that the potential rearranged cation $81(\mathrm{E}=\mathrm{CN})$ is not even an energy minimum, but a transition state.

\section{Conclusion}

1-Substituted-cis-2-trimethylsilylyclopropylcarbinyl mesylates and triflates 13 solvolyze in $\mathrm{CD}_{3} \mathrm{CO}_{2} \mathrm{D}$ to give products derived from 3-trimethylsilylcyclobutyl cations. These cationic intermediates are stabilized by a long-range rear lobe interaction with the $\gamma$-trimethylsilyl group. When the substituent is electronwithdrawing $\left(\mathrm{CF}_{3}, \mathrm{CN}\right.$, or $\left.\mathrm{CO}_{2} \mathrm{CH}_{3}\right)$, significant amounts of bicyclobutane products are formed. The bicyclobutanes are a result of $\gamma$-trimethylsilyl elimination from the cationic intermediate. Computational studies support a carbocation intermediate with an unusually long $\mathrm{Si}-\mathrm{C}$ bond, indicative of increased demand for $\mathrm{Si}-\mathrm{C}$ hyperconjugation due to the electron-withdrawing group. With the exception of the phenyl substitution, 
the chemistry of trans-derivatives $\mathbf{1 4}$ is quite different since these substrates are geometrically precluded from forming $\gamma$-trimethylsilyl-stabilized cyclobutyl cations.

\section{Experimental}

Full experimental details are given in Supporting Information File 1.

\section{Supporting Information}

Full experimental details, ${ }^{1} \mathrm{H}$ and ${ }^{13} \mathrm{C}$ NMR spectra of new compounds, and M062X/6-311+G** computational studies are presented as Supporting Information.

\section{Supporting Information File 1}

Experimental details and ${ }^{1} \mathrm{H}$ and ${ }^{13} \mathrm{C}$ NMR spectra of new compounds.

[https://www.beilstein-journals.org/bjoc/content/ supplementary/1860-5397-15-170-S1.pdf]

\section{Supporting Information File 2}

M062X/6-611+G** calculated structures, energies, and Cartesian coordinates for carbocations and transition states. [https://www.beilstein-journals.org/bjoc/content/ supplementary/1860-5397-15-170-S2.pdf]

\section{ORCID ${ }^{\circledR}$ iDs}

Xavier Creary - https://orcid.org/0000-0002-1274-5769

\section{References}

1. Merling, G. Ber. Dtsch. Chem. Ges. 1891, 24, 3108-3126. doi:10.1002/cber.189102402151

2. von E. Doering, W.; Knox, L. H. J. Am. Chem. Soc. 1954, 76, 3203-3206. doi:10.1021/ja01641a027

3. Norris, J. F.; Sanders, W. W. Am. Chem. J. 1901, 25, 54-62.

4. Kehrmann, F.; Wentzel, F. Ber. Dtsch. Chem. Ges. 1901, 34, 3815-3819. doi:10.1002/cber.19010340393

5. Gomberg, M. Ber. Dtsch. Chem. Ges. 1907, 40, 1847-1888. doi:10.1002/cber.19070400289

6. Freedman, H. H. In Carbonium lons; Olah, G. A.; von Ragué Schleyer, P., Eds.; Wiley Interscience: New York, U.S.A., 1973; Vol. IV, pp 1501-1578. See for a review and leading references.

7. Horn, M.; Mayr, H. J. Phys. Org. Chem. 2012, 25, 979-988. doi:10.1002/poc.2979 See for a review and leading references.

8. Richey, H. G., Jr. In Carbonium Ions; Olah, G. A.; von Ragué Schleyer, P., Eds.; Wiley Interscience: New York, U.S.A., 1972; Vol. III, pp 1201-1294.

See for a leading review.
9. Wiberg, K. B.; Hess, B. A., Jr.; Ashe, A. J., III. In Carbonium lons; Olah, G. A.; von Ragué Schleyer, P., Eds.; Wiley Interscience: New York, U.S.A., 1972; Vol. III, pp 1295-1345.

See for a leading review.

10. Demjanow, N. J. Ber. Dtsch. Chem. Ges. 1907, 40, 4961-4963. doi:10.1002/cber.190704004168

11. Roberts, J. D.; Mazur, R. H. J. Am. Chem. Soc. 1951, 73, 2509-2520. doi:10.1021/ja01150a029

12. Sneen, R. A.; Lewandowski, K. M.; Taha, I. A. I.; Smith, B. R. J. Am. Chem. Soc. 1961, 83, 4843-4848. doi:10.1021/ja01484a035

13. Roberts, J. D.; Mazur, R. H. J. Am. Chem. Soc. 1951, 73, 3542-3543. doi:10.1021/ja01151a550

14. Caserio, M. C.; Graham, W. H.; Roberts, J. D. Tetrahedron 1960, 11 , 171-182. doi:10.1016/0040-4020(60)80068-3

15. von Ragué Schleyer, P.; Majerski, Z. J. Am. Chem. Soc. 1971, 93, 665-671. doi:10.1021/ja00732a019

16. Olah, G. A.; Reddy, V. P.; Prakash, G. K. S. Chem. Rev. 1992, 92, 69-95. doi:10.1021/cr00009a003

17. Saunders, M.; Siehl, H. U. J. Am. Chem. Soc. 1980, 102, 6868-6869. doi:10.1021/ja00542a045

18. Staral, J. S.; Yavari, I.; Roberts, J. D.; Prakash, G. K. S.; Donovan, D. J.; Olah, G. A. J. Am. Chem. Soc. 1978, 100, 8016-8018. doi:10.1021/ja00493a045

19. Koch, W.; Liu, B.; DeFrees, D. J. J. Am. Chem. Soc. 1988, 110 , 7325-7328. doi:10.1021/ja00230a008

20. Siehl, H.-U. Adv. Phys. Org. Chem. 2018, 52, 1-47. doi:10.1016/bs.apoc.2018.10.001

21. Creary, X. Chem. Rev. 1991, 91, 1625-1678. doi:10.1021/cr00008a001

22. Gassman, P. G.; Tidwell, T. T. Acc. Chem. Res. 1983, 16, 279-285. doi:10.1021/ar00092a003

23. Tidwell, T. T. Angew. Chem., Int. Ed. Engl. 1984, 23, 20-32. doi:10.1002/anie.198400201

24. Allen, A. D.; Tidwell, T. T. In Advances in Carbocation Chemistry; Creary, X., Ed.; Jai Press Inc.: Greenwich, CT, 1989; Vol. 1, pp 1-44.

25. Gassman, P. G.; Talley, J. J. J. Am. Chem. Soc. 1980, 102, 1214-1216. doi:10.1021/ja00523a076

26. Gassman, P. G.; Talley, J. J. J. Am. Chem. Soc. 1980, 102, 4138-4143. doi:10.1021/ja00532a026

27. Dixon, D. A.; Charlier, P. A.; Gassman, P. G. J. Am. Chem. Soc. 1980, 102, 3957-3959. doi:10.1021/ja00531a051

28. Gassman, P. G.; Saito, K. Tetrahedron Lett. 1981, 22, 1311-1314. doi:10.1016/s0040-4039(01)90304-1

29. Gassman, P. G.; Guggenheim, T. L. J. Org. Chem. 1982, 47, 3023-3026. doi:10.1021/jo00136a048

30. Begue, J. P.; Charpentier-Morize, M. Acc. Chem. Res. 1980, 13, 207-212. doi:10.1021/ar50151a003

31. Creary, X. Acc. Chem. Res. 1985, 18, 3-8. doi:10.1021/ar00109a002

32. Creary, X. In Advances in Carbocation Chemistry; Creary, X., Ed.; Jai Press Inc.: Greenwich, CT, 1989; Vol. 1, pp 45-92.

33. Charpentier-Morize, M.; Begue, J.-P. In Advances in Carbocation Chemistry; Creary, X., Ed.; Jai Press Inc.: Greenwich, CT, 1989; Vol. 1, pp 219-253.

34. Creary, X.; Geiger, C. C.; Hilton, K. J. Am. Chem. Soc. 1983, 105, 2851-2858. doi:10.1021/ja00347a054

35. Creary, X.; Underiner, T. L. J. Org. Chem. 1985, 50, 2165-2170. doi:10.1021/jo00212a033 
36. Siehl, H.-U. In Recent Developments in Carbocation and Onium Ion Chemistry; Laali, K. K., Ed.; ACS Symposium Series No. 965; American Chemical Society: Washington, DC, 2007; pp 1-31. See for a review and leading references.

37. Siehl, H.-U.; Müller, T. In The Chemistry of Organosilicon Compounds; Rappoport, Z.; Apeloig, Y., Eds.; John Wiley and Sons: New York, U.S.A.; Vol. 2, pp 595-701. See for a review and leading references.

38. Lambert, J. B.; Zhao, Y.; Emblidge, R. W.; Salvador, L. A.; Liu, X.; So, J. H.; Chelius, E. C. Acc. Chem. Res. 1999, 32, 183-190. doi:10.1021/ar970296m See for a review and leading references.

39. Lambert, J. B.; Liu, X. J. Organomet. Chem. 1996, 521, 203-210. doi:10.1016/0022-328x(96)06228-6 See for a review and leading references.

40. Lambert, J. B. Tetrahedron 1990, 46, 2677-2689. doi:10.1016/s0040-4020(01)88362-9 See for a review and leading references.

41. Lambert, J. B.; Chelius, E. C. J. Am. Chem. Soc. 1990, 112, 8120-8126. doi:10.1021/ja00178a041 See for a review and leading references.

42. Lambert, J. B.; Wang, G. T.; Finzel, R. B.; Teramura, D. H. J. Am. Chem. Soc. 1987, 109, 7838-7845. doi:10.1021/ja00259a036 See for a review and leading references.

43. White, J. M. Aust. J. Chem. 1995, 48, 1227-1251. doi:10.1071/ch9951227 See for a review and leading references.

44. Sommer, L. H.; Bailey, D. L.; Whitmore, F. C. J. Am. Chem. Soc. 1948, 70, 2869-2872. doi:10.1021/ja01189a009 See for a review and leading references.

45. Creary, X.; Butchko, M. A. J. Am. Chem. Soc. 2001, 123, 1569-1578. doi:10.1021/ja002407+

46. Creary, X.; Butchko, M. A. J. Org. Chem. 2001, 66, 1115-1121. doi:10.1021/jo001112b

47. Creary, X.; Jiang, Z.; Butchko, M.; McLean, K. Tetrahedron Lett. 1996, 37, 579-582. doi:10.1016/0040-4039(95)02266-X

48. Creary, X.; Wang, Y.-X. Tetrahedron Lett. 1989, 30, 2493-2496. doi:10.1016/s0040-4039(01)80433-0

49. Creary, X.; Kochly, E. D. J. Org. Chem. 2009, 74, 2134-2144. doi:10.1021/j0802722z

50. Creary, X.; O'Donnel, B. D.; Vervaeke, M. J. Org. Chem. 2007, 72, 3360-3368. doi:10.1021/j0062668n

51. Siehl, H.-U.; Fulj, M. Pure Appl. Chem. 1998, 70, 2015-2022. doi:10.1351/pac199870102015

52. Creary, X.; Kochly, E. D. J. Org. Chem. 2009, 74, 9044-9053. doi:10.1021/jo901821f

53. Creary, X.; Heffron, A. J. Org. Chem. 2014, 79, 2547-2555. doi:10.1021/jo500007p

54. Creary, X.; Heffron, A.; Going, G.; Prado, M. J. Org. Chem. 2015, 80, 1781-1788. doi:10.1021/j0502691t

55. Mercadante, M. A.; Kelly, C. B.; Hamlin, T. A.; Delle Chiaie, K. R.; Drago, M. D.; Duffy, K. K.; Dumas, M. T.; Fager, D. C.; Glod, B. L. C.; Hansen, K. E.; Hill, C. R.; Leising, R. M.; Lynes, C. L.; MacInnis, A. E.; McGohey, M. R.; Murray, S. A.; Piquette, M. C.; Roy, S. L.; Smith, R. M.; Sullivan, K. R.; Truong, B. H.; Vailonis, K. M.; Gorbatyuk, V.; Leadbeater, N. E.; Tilley, L. J. Chem. Sci. 2014, 5, 3983-3994. doi:10.1039/c4sc01732c

56. Shiner, V. J., Jr.; Ensinger, M. W.; Kriz, G. S. J. Am. Chem. Soc. 1986, 108, 842-844. doi:10.1021/ja00264a050
57. Shiner, V. J., Jr.; Ensinger, M. W.; Huffman, J. C. J. Am. Chem. Soc. 1989, 111, 7199-7205. doi:10.1021/ja00200a045

58. Grob, C. A.; Gründel, M.; Sawlewicz, P. Helv. Chim. Acta 1988, 71 , 1502-1507. doi:10.1002/hlca.19880710615

59. Adcock, W.; Clark, C. I.; Schiesser, C. H. J. Am. Chem. Soc. 1996, 118, 11541-11547. doi:10.1021/ja961870c

60. Creary, X. J. Am. Chem. Soc. 2013, 135, 6570-6578. doi:10.1021/ja400747u

61. Creary, X. J. Org. Chem. 2015, 80, 11378-11387. doi:10.1021/acs.joc.5b01955

62. Mascitti, V.; Corey, E. J. J. Am. Chem. Soc. 2006, 128, 3118-3119. doi:10.1021/ja058370g

63. Ohta, H.; Ishizaka, T.; Tatsuzuki, M.; Yoshinaga, M.; lida, I.; Yamaguchi, T.; Tomishima, Y.; Futaki, N.; Toda, Y.; Saito, S. Bioorg. Med. Chem. 2008, 16, 1111-1124. doi:10.1016/j.bmc.2007.10.087

64. Hsee, L. C.; Sardella, D. J. Magn. Reson. Chem. 1990, 28, 688-692. doi:10.1002/mrc.1260280806

65. Chen, J.; Reibenspies, J.; Derecskei-Kovacs, A.; Burgess, K. Chem. Commun. 1999, 2501-2502. doi:10.1039/a907559c

66. Creary, X. J. Am. Chem. Soc. 1984, 106, 5568-5577. doi:10.1021/ja00331a029

67. Jansen, M. P.; Koshy, K. M.; Mangru, N. N.; Tidwell, T. T. J. Am. Chem. Soc. 1981, 103, 3863-3867. doi:10.1021/ja00403a040

\section{License and Terms}

This is an Open Access article under the terms of the Creative Commons Attribution License (http://creativecommons.org/licenses/by/4.0). Please note that the reuse, redistribution and reproduction in particular requires that the authors and source are credited.

The license is subject to the Beilstein Journal of Organic Chemistry terms and conditions:

(https://www.beilstein-journals.org/bjoc)

The definitive version of this article is the electronic one which can be found at: doi: $10.3762 /$ bjoc. 15.170 